\title{
Wrestling with evidence-based medicine
}

W restlers and bodybuilders used to scare me, absolutely petrify me out of my wits, and my self-confidence evaporated forthwith. Make no mistake I do think of myself as a big guy but my bigness is more vertical, whereas my transverse growth was rather prematurely stunted. But that doesn't worry me these days. I am now a transformed character. With the help of my longtime patient, Leo, I have rediscovered my inner strength, and steely resolve. Even my children look at their "new" dad with an immense pride in their eyes!

It all began when I walked into the office with my resident, Jennifer, to see Leo. We had recently started Leo on insulin for his type 2 diabetes, and Leo was not happy with it. In fact, he was so unhappy that he came for his appointment wearing a T-shirt with a huge picture of his wrestling idol, Goldberg, the man mountain of wrestling, proudly displayed on his chest.

"I don't like insulin," Leo informed me even before I had the chance to finish greeting him; "And, I don't like people who try to hurt me with needles either." After having satisfied himself by seeing the distinct shade of pallor that must have crept into my face, he added his coup de grâce by informing me that he had been lifting weights at the local gym. Now, you don't fool around with Leo unless you have a streak of masochism in you. Leo was not only a Goldberg fan he looked like Goldberg.

"But Leo, you do need insulin to control your diabetes, otherwise we will have to go back to the pills ... and remember they were becoming ineffective before we decided to add insulin," I meekly tried to explain my position to Leo. "Precisely," says Leo, "that's why I o don't want to take the pills either." This exchange was followed by a lengthy "evidence-based" sermon on my part about the usual risks of leaving diabetes untreated, which Leo heard with half amusement and half consternation.

"I have a proposition for you Doc; do you want to hear that?" said Leo after I finished my babble. Then, without hearing my response, he faced Jennifer, and asked her to leave the room so that he could discuss the matter with me "man to man." I looked imploringly at Jennifer not to do so, but she was already halfway out the door.

I sat there numb with fear, trying my best to look calm and in control of the situation. Leo put his massive arm on the table, looked squarely into my eyes and said "Let's sort it out man-to-man; we will do arm wrestling, and if you win, I will do as you say." Now that was an unfair proposition, because Leo was not regarded as an avid wrestling fan for nothing and he had a reputation to keep.

"Alright then, but you will have to promise me to look after your diabetes, if I win," I said and the pact was sealed.

The rest is history.

Leo is now religiously looking after his diabetes and taking his medication and me, well, at least I have nothing more to fear from the wrestling fans. As for the wrestlers, and proponents of evidencebased practice, that's another story.

\section{S. Ali Imran}

Endocrinologist

Halifax, NS

\section{Poem}

\section{Apparition}

scant couple seconds that dreaded whine

to stinking puff of mortar sent

wherein on target right on time

life's blood once more is freely spent

were it I there

putrefaction 'neath that cross

are you then born

some spectral seed of phantom loss

child of child of soldier spared mark well the lesson of the dead troubled restive 'til all may hear it

pray yield not youth nor joyous spirit to mindless dictates overhead

cheated twice and no one caring forgotten and

\section{forever barren}

\author{
Leonard Zimich, MD \\ Veteran of World War II \\ New Westminster, BC \\ This poem was written to the author's \\ grandson, posted with the Canadian \\ Army Reserve in Germany
}

